\title{
Canine Mammary Carcinomas: A Comparative Analysis of Altered Gene Expression
}

\author{
Farruk M. Lutful Kabir ${ }^{1,2}$, Carlos E. Alvarez ${ }^{3}$ and R. Curtis Bird ${ }^{1, *}$
}

Received: 2 June 2015; Accepted: 21 December 2015; Published: 25 December 2015

Academic Editor: Jaime Modiano

1 Auburn University Research Initiative in Cancer (AURIC), Department of Pathobiology,

College of Veterinary Medicine, Auburn University, AL 36849, USA; fz10005@auburn.edu

2 Current address: Department of Pediatrics, Division of Pulmonology,

University of Alabama at Birmingham, Birmingham, AL 35294, USA

3 Center for Molecular and Human Genetics, The Research Institute at Nationwide Children's Hospital Departments of Pediatrics and Veterinary Clinical Sciences, The Ohio State University Colleges of Medicine and Veterinary Medicine, Columbus, OH 43205, USA; Carlos.Alvarez@nationwidechildrens.org

* Correspondence: birdric@auburn.edu; Tel.: +1-334-844-4539; Fax: +1-334-844-2652

\begin{abstract}
Breast cancer represents the second most frequent neoplasm in humans and sexually intact female dogs after lung and skin cancers, respectively. Many similar features in human and dog cancers including, spontaneous development, clinical presentation, tumor heterogeneity, disease progression and response to conventional therapies have supported development of this comparative model as an alternative to mice. The highly conserved similarities between canine and human genomes are also key to this comparative analysis, especially when compared to the murine genome. Studies with canine mammary tumor (CMT) models have shown a strong genetic correlation with their human counterparts, particularly in terms of altered expression profiles of cell cycle regulatory genes, tumor suppressor and oncogenes and also a large group of non-coding RNAs or microRNAs (miRNAs). Because CMTs are considered predictive intermediate models for human breast cancer, similarities in genetic alterations and cancer predisposition between humans and dogs have raised further interest. Many cancer-associated genetic defects critical to mammary tumor development and oncogenic determinants of metastasis have been reported and appear to be similar in both species. Comparative analysis of deregulated gene sets or cancer signaling pathways has shown that a significant proportion of orthologous genes are comparably up- or down-regulated in both human and dog breast tumors. Particularly, a group of cell cycle regulators called cyclin-dependent kinase inhibitors (CKIs) acting as potent tumor suppressors are frequently defective in CMTs. Interestingly, comparative analysis of coding sequences has also shown that these genes are highly conserved in mammals in terms of their evolutionary divergence from a common ancestor. Moreover, co-deletion and/or homozygous loss of the INK4A/ARF/INK4B (CDKN2A/B) locus, encoding three members of the CKI tumor suppressor gene families (p16/INK4A, p14ARF and $\mathrm{p} 15 / \mathrm{INK} 4 \mathrm{~B})$, in many human and dog cancers including mammary carcinomas, suggested their important conserved genetic order and localization in orthologous chromosomal regions. miRNAs, as powerful post-transcriptional regulators of most of the cancer-associated genes, have not been well evaluated to date in animal cancer models. Comprehensive expression profiles of miRNAs in CMTs have revealed their altered regulation showing a strong correlation with those found in human breast cancers. These genetic correlations between human and dog mammary cancers will greatly advance our understanding of regulatory mechanisms involving many critical cancer-associated genes that promote neoplasia and contribute to the promising development of future therapeutics.
\end{abstract}

Keywords: canine; mammary cancer; oncogenes; tumor suppressor genes 


\section{Introduction}

In the field of human cancer research, there is an intense interest in development of appropriate model systems for the advancement of future therapeutic inventions. Companion animals such as domesticated dogs (Canis lupus familiaris) are considered excellent preclinical models of cancers and other complex human diseases for many reasons, including their easy accessibility and living status in diverse cultures [1]. Since they are treated as pet animals, most of the dog population shares the same environment, risk factors or disease characteristics with the human population [2,3] which provides an added advantage for scientists to investigate cancer etiologies. Additionally, dogs represent a more outbred population than inbred laboratory animals providing a genetic diversity similar to that observed in humans [4].

Canine models address two important issues in cancer research. First, in terms of similarities, dogs spontaneously develop cancers in the context of a natural immune system with a clinical presentation, tumor genetics and heterogeneity, disease progression and response to conventional therapies [5] that better models the complex biology of cancers and their interactions with the immune system in human patients than mouse models. The similarities between the dog and human genomes have also greatly enhanced comparative genomic analysis. With the advent of the high resolution 2.4 billion bp canine genome sequence and the identification of nearly all of its genes as clear orthologs of known human genes [4], the dog has emerged as a valuable comparative and intermediate model for the study of human cancers. The high level of sequence conservation between canine and human genomes are key to this comparative analysis especially since $600 \mathrm{Mb}$ of DNA sequence conserved between dog and human is missing from the murine genome [1]. Secondly, using dogs as animal models may contribute to the development of cancer therapeutics for, not only human and dog, but also other species - a promising theme lately coined as "One Medicine" that campaigns under a unified scientific platform where discoveries in one species can be translated to others to improve health management in all species. Canine tumors with potential relevance for human cancer biology include osteosarcoma, mammary carcinoma, lymphoma, melanoma, lung carcinoma, and soft tissue sarcomas [6].

\section{Canine Mammary Tumors (CMTs)}

Mammary tumors are the most common neoplasm in sexually intact female dogs. The severity of canine mammary tumors (CMT) can be appreciated from a number of studies that reported increased rates of incidence in the dog population globally. Breast cancer represents the second most frequent neoplasm in humans and all dogs after lung and skin cancers, respectively, although many reports indicate that dogs are two to four times more susceptible to mammary cancers than women in certain geographical areas [7-10]. Nearly 50\% of all these neoplasms are diagnosed as malignant and more than $95 \%$ of these malignant CMTs are carcinomas [11,12].

Canine mammary carcinomas are biologically heterogeneous neoplasms offering several ways to classify such tumors on the basis of histopathological characteristics or expression of molecular markers [13]. Despite the appearance of histomorphological variations between human and canine breast cancers, due to various prognostic indicators, a number of studies have reported that there are significant similarities regarding molecular marker expression, hormone dependency and cancer phenotypes [11-14]. It is important to classify breast cancer in order to correlate clinical phenotypes, invasion or grade of progression and to develop prognostic markers. The human classification of breast cancers based on expression profile of luminal epithelial specific genes and hormone receptors including estrogen receptor 1 (ESR1), progesterone receptor (PR) and proto-oncogenes such as epidermal growth factor receptors (EGFR/HER2), have also identified similar molecular subtypes in CMTs, but unlike human subtypes, these are not routinely investigated for CMTs during clinical diagnosis $[15,16]$. Recently, in more refined studies employing immunohistochemical approaches and based on the characteristic expression patterns of ESR1, PR and EGFR (ERBB1/HER1, ERBB2/HER2, ERBB3 and ERBB4), human-like breast cancer phenotypes for CMTs have been developed 
and classified as luminal A, luminal B, HER2 positive and triple negative (basal-like) $[17,18]$. Such standard classification therefore strongly supports canine mammary tumors as valuable intermediate models for human breast cancer that should be well-placed for developing diagnostic and treatment strategies.

Because CMTs are considered predictive models for human breast cancer [6], similarities in genetic alterations and cancer predisposition between humans and dogs have raised interest even further. A large number of studies have demonstrated that CMTs have many similarities in molecular and clinical features with human breast cancer. Many genetic/epigenetic/tumor biology traits that are most frequently associated with mammary cancer have been identified and comparative gene expression analysis has revealed a significant similarity in the canine and human genes associated with mammary tumor development [19]. Although CMTs have not yet been classified based on surface markers, due to an absence of appropriate antibodies identifying human breast cancer subtypes, the expression profile of vital genes involved in cellular proliferation, angiogenesis, apoptosis, cell cycle regulation, DNA damage repair, signal transduction, and survival pathways firmly correlate to those in human breast cancer $[19,20]$. These studies characterized CMTs, based on genome-wide gene expression changes, comparing to human breast cancer, suggesting that mutations and alterations in the cancer genome may promote deregulation of individual genes in mammary cancers.

Comparative analysis of deregulated gene sets or cancer signaling pathways showed that a significant proportion of orthologous genes are comparably up- and down-regulated in both human and canine breast tumors. Prominent oncogenic pathways and related genes, such as PI3K/AKT, KRAS, MAPK, Wnt, $\beta$-catenin, BRCA2, ESR1 and P-cadherin, are commonly up-regulated while representative tumor suppressive pathways, such as p53, p16/INK4A, PTEN and E-cadherin, are down-regulated in human and canine breast cancer [19,21-25]. This chapter will discuss the comparative aspects of cell cycle regulatory genes, particularly the evolutionary descent, structure, genomic localization, biological functions, expression defects and post-transcriptional regulation of the CDKN2/INK4 family of cyclin-dependent kinase inhibitors (CKIs) in canine and human breast cancers.

\section{Cell Cycle Regulators: A Classic Repertoire of Tumor Suppressors}

From simple eukaryotes such as yeast to higher mammals, the cell cycle serves as a fundamental biological process by which cells grow and divide and its regulation is central to cancer promoting mechanisms. Cancer causes are complex involving dysregulation of cellular functions and dysregulation in micro-environmental signaling as well as being rooted in oncogenic mutations [26]. Ultimately, cancers occur due to an alteration in the regulation of cell proliferation. Cell proliferation itself is rooted in the cell cycle which is a highly regulated process governed by complex mechanisms [27]. The uncontrolled cell proliferation in cancer is also associated with a vicious cycle where cells divide through unchecked cell cycle progression with a reduction in sensitivity to signals that normally guide cells to adhere, become quiescent, terminally differentiate or die. This combination of unregulated proliferation and a failure of balancing suppressor activities is hallmark of malignant transformation resulting in neoplasia that can eventually develop the ability to spread and migrate throughout the body through metastasis [28]. One such group of genetic alterations that contribute to cancer development are often termed hypermorphic mutations that largely define oncogenes and result from the mutated versions of normal cellular proto-oncogenes. Oncogenic mutations appear to destroy the integrity and modulated control of cell proliferation first by altering control of the stimulatory pathways that promote cell growth. They may also promote neoplasia by suppressing those pathways normally responsible for modulating and inhibiting proliferation or causing exit from the cell cycle entirely. These "loss of function" mutations occur in tumor suppressor genes that encode proteins that can negatively regulate cell cycle progression but, when mutated, are permissive for cancer development and can promote spontaneous as well as, 
in some instances, hereditary forms of cancer [29]. Two important examples of such loss-of-function mutations affecting cell cycle regulation are mutations in the retinoblastoma $(\mathrm{Rb})$ and $\mathrm{p} 16 / \mathrm{INK} 4 \mathrm{~A}$ tumor suppressor genes [30,31]. Loss of function of these tumor suppressor gene products results in liberation of the E2F transcription factors, associated with $S$ phase promotion, that consequently remove control of cell cycle exit during G1 phase resulting in abnormal and continuous cellular proliferation [29].

A group of inhibitory proteins, called cyclin-dependent kinases inhibitors (CKIs) or CDK inhibitors, control cyclin-CDK activity thereby restraining cell cycle progression in response to extracellular and intracellular signals [32,33]. The orderly progression of the cell cycle is fine-tuned by the genes encoding such negative regulators, or CKIs, and positive regulators including the cyclins and CDKs. Dysregulation of these genes can lead to premature and unregulated entry into the next phase of the cell cycle leaving the previous phase unchecked, and frequently this occurs prior to completion of critical molecular events such as repair of DNA damage or replication errors. Such dysfunction frequently triggers genomic instability and neoplastic transformation. Based on their structural similarities and specific roles in cell cycle regulation, CKIs are divided into two distinct groups: the INK4, or CDKN2, and the Cip/Kip, or CDKN1, families [33]. The first group representing the INK4 proteins (Inhibitors of CDK4) are so named because of their ability to specifically inhibit the catalytic subunits of CDK4 and CDK6. It has been reported that INK4 proteins compete with cyclin D for binding to the CDK4/6 subunit [34,35]. The members of the INK4 protein family that share common structural features are p16/INK4A (and p14ARF, an alternatively spliced product from the same locus), p15/INK4B, p18/INK4C and p19/INK4D (Figure 1) [36-38]. The Cip/Kip family (for CDK interacting protein/ Kinase inhibitory protein) consists of three members, including p21/Cip1, p27/Kip1 and p57/Kip2, all of which share a common inhibitory domain that enables them to bind CDK complexes [37,39]. These proteins of the Cip/Kip family have broad specificity for binding and inhibiting a number of cyclin-CDK complexes compared to that of INK 4 members. They also inhibit the activity cyclin D-CDK4 preventing Rb phosphorylation during G1 to S phase transition. In addition, they inhibit cyclin A-CDK2 in late G1 phase and cyclin E-CDK2 in early $S$ phase (Figure 1) [37]. Therefore, both CKI families are important modulating components of the complex network of cell cycle regulatory mechanisms.

\subsection{CDK Inhibitors Form a Repertoire of Tumor Suppressor Proteins}

Many studies stress the fact that CDKs are positive regulators and CKIs are negative regulators of cell proliferation based on their distinct inhibitory actions in the eukaryotic cell cycle [38,40]. Besides their specific roles in cell cycle regulation, differentiation and development, CKIs are proven or highly likely tumor suppressors to have this potential, as mutations in these genes promote malignant phenotypes $[32,36,37,41]$. In some clinical trials, CKI tumor suppressors aggressively promote cancer cell growth by inducing p53 function and stability and increasing anti-proliferative activity thereby inhibiting cell cycle progression [42]. Among all the CKIs, p16/INK4A is the founding member and was the first classified as a major tumor suppressor gene (only preceded by p53 for many human malignancies) because the mutations in the INK4A/ARF locus, and loss of heterozygosity of the chromosomal region encoding this gene, have been reported in a wide range of cancers including melanomas, leukemias, gliomas, lung, breast and bladder cancers [36,41]. The loss of expression of the neighboring p15/INK4B gene, due to promoter hypermethylation, also occurs in a number of leukemias and lymphomas [38,43]. The p16/INK4A locus has also been found to be frequently mutated in canine malignant melanomas, mammary carcinomas and fibrosarcomas [21,44-47]. 


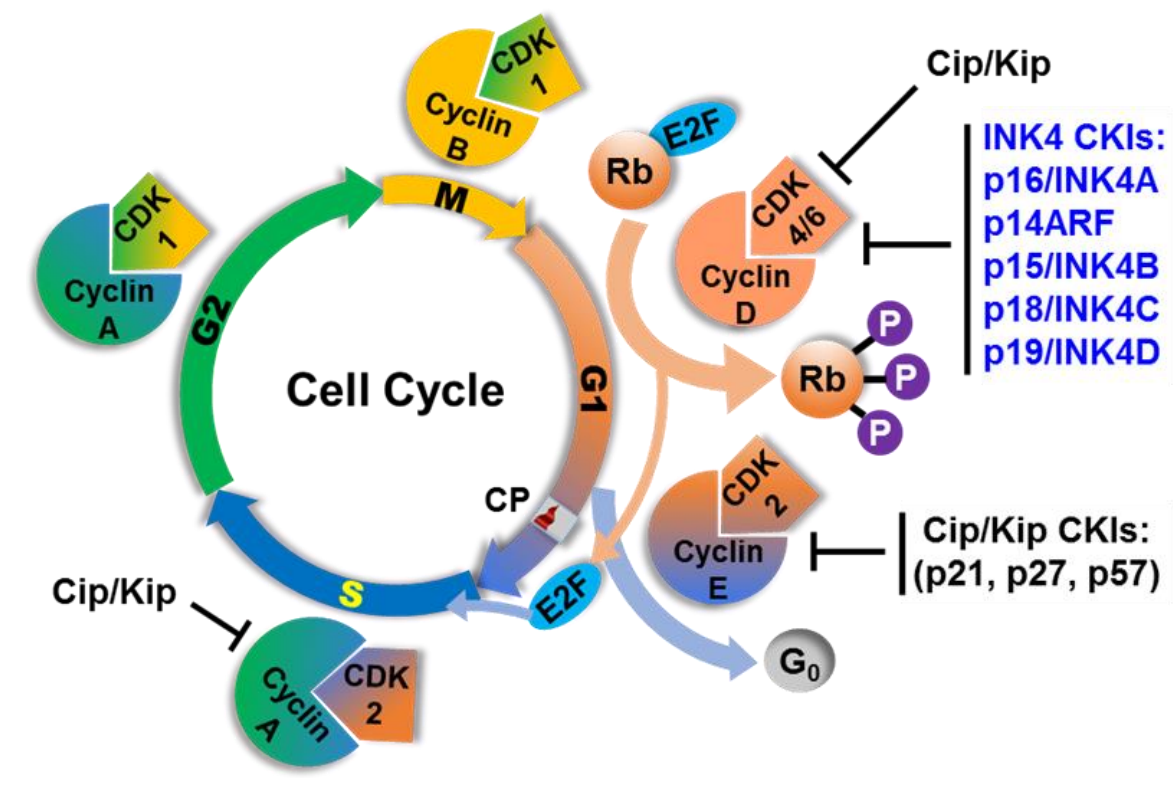

Figure 1. Cyclin-Dependent Kinase Inhibitors (CKIs) are regulators of the cell cycle. Cell cycle phases, major regulatory proteins or protein complexes including cyclins, CDKs, INK4 and Cip/Kip inhibitors and their targets are shown. Checkpoint $(\mathrm{CP})$ or major restriction point.

\subsection{Evolutionary History, Genomic Localization and Structure of the INK4A/ARF Locus}

A locus on the short arm of human chromosome 9p21 (a known multiple tumor suppressor locus) encodes three products called p16/INK4A, p14ARF and p15/INK4B, all of which regulate cell proliferation by inhibiting the cyclin-CDK complex at the G1 to $S$ phase transition in the cell cycle [36,41]. The organization of the INK4A/ARF/INK4B (or INK4A/ARF) locus in the mammalian genome is highly conserved. Orthologous sequence searches and comparative genomics analysis has demonstrated that this locus in human (chromosome 9) is syntenic to that of chimp (chromosome 9), dog (chromosome 11), cat (chromosome D4), mouse (chromosome 4) and rat (chromosome 5) and this region, encoding several tumor suppressor genes, is highly susceptible to genetic instability and mutations in many cancers $[36,37,48]$. The close similarities between the INK4A and INK4B genes and two other members of the INK4 CKI gene family, INK4C and INK4D based on their protein sequence, biochemical properties and functions in the cell cycle, suggest that they arose as a result of gene duplication during the course of evolution. This is most likely true since a number of studies have demonstrated that all four INK4 CKIs share a common structural feature called ankyrin repeats that appear to function as a structural scaffold facilitating protein-protein interactions and these four CKIs also appear functionally related $[36,49,50]$.

The evolutionary history of the INK4A/ARF/INK4B locus suggests that the INK4 genes have evolved through tandem gene duplication events. One of the most interesting findings for the evolutionary descent of INK4 genes was the complete absence of ARF-like gene products in the Japanese puffer fish Fugu rubripes (fugu) and in the zebrafish $[37,48]$ suggesting that p14ARF was introduced into the vertebrate or mammalian genome following INK4 duplication. Three unique INK4 genes, representing INK4A or B, INK4C and INKD have been identified in the fugu genome (Figure 2). Evolutionarily, p16/INK4A and p15/INK4B are products of a local tandem duplication while p18/INK4C and p19INK4D are present on other chromosomes [37,48]. Cross-species comparative analysis suggested that a single common ancestral INK4 gene was present and a series of duplication and rearrangement events first gave rise to INK4A/B and INK4C/D-like elements in a common vertebrate ancestor and after the divergence of higher vertebrates from tetrapod and fish approximately 350 million years ago (MYA) gave rise to the individual INK4 genes in the mammalian genome [37]. 


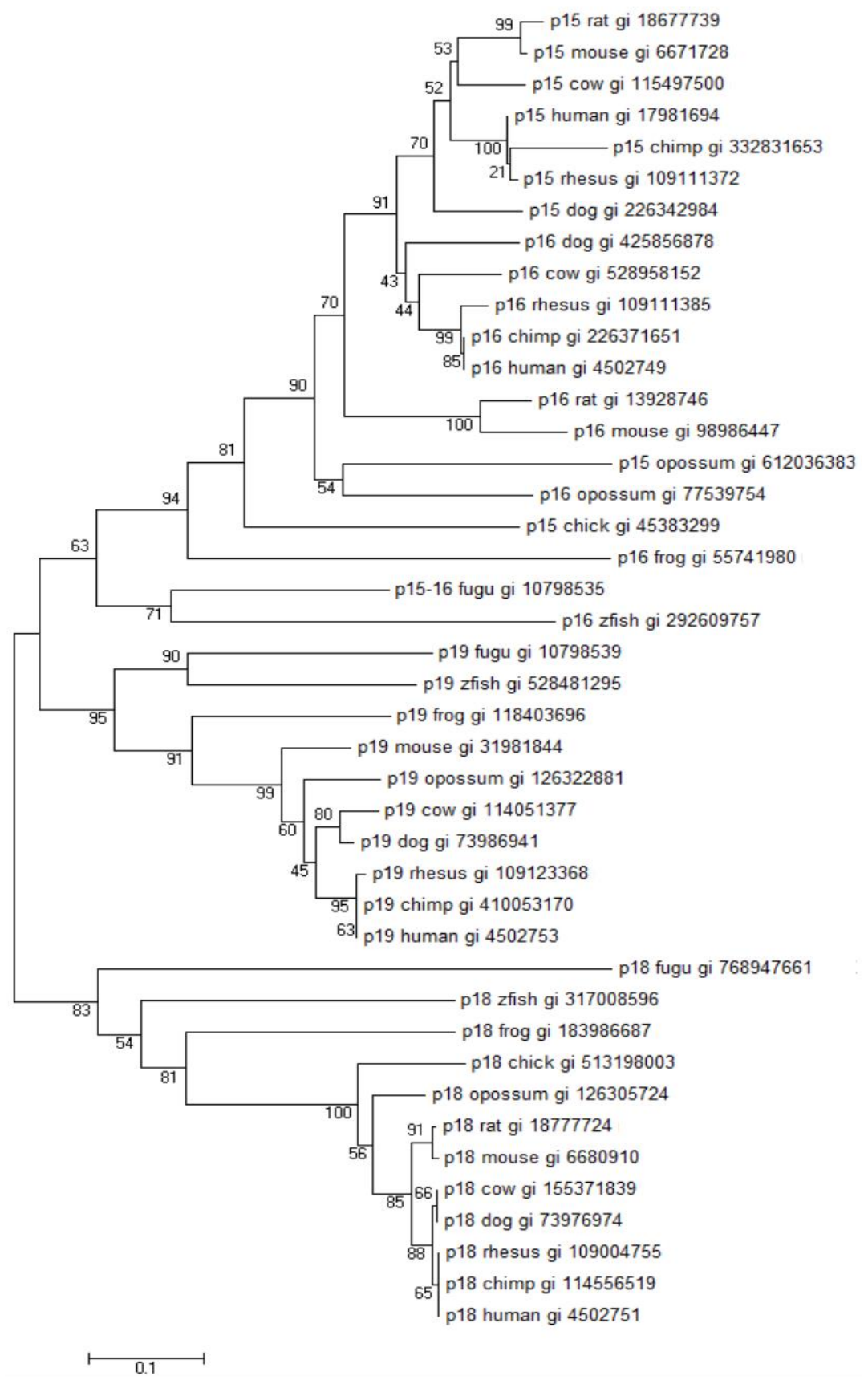

Figure 2. INK4/CDKN2 family tree. Annotated INK4 proteins from select organisms were aligned using Clustal W. The alignment was used to construct a neighbor-joining phylogenetic tree (applying complete deletion of gaps and Poisson model rates and patterns; MEGA6). Bootstrap values were calculated from 500 repetitions. Similar results were achieved with maximum parsimony phylogenetic treeing (not shown). The phylogenetic analyses (see text) demonstrate the high similarity and conservation among INK4 proteins as well as their evolutionary descent. The scale bar shows the number of substitutions per site. NCBI GI accession numbers of the proteins are given on the tree along with the common or abbreviated animal name. Taxonomy abbreviations follow: zfish, Danio rerio (zebrafish); fugu, Takifugu rubripes (Japanese puffer fish); Xenopus tropicalis (western clawed frog); chick, Gallus gallus (chicken, red junglefowl); opossum, Monodelphis domestica; cow, Bos taurus; dog, Canis lupus familiaris; rat, Rattus norvegicus (Norway rat); mouse, Mus musculus (house mouse); rhesus, Macaca mulatta (Rhesus macaque); chimp, Pan troglodytes (common chimpanzee); human, Homo sapiens. 
These evolutionary changes placed p16/INK4A and p15/INK4B about $30 \mathrm{~kb}$ apart in the same transcriptional orientation on chromosome 9p21 whereas p18/INK4C and p19/INK4D are present on human chromosomes 1p32 and 19p13, respectively [36]. Phylogenetic trees based on the published amino acid sequences of INK4 proteins indicates their high similarities among groups and likely divergence from a common ancestor (Figure 2). This evolutionary relationship suggests that the p16/INK4A and p15/INK4B from mammals represent a paralogous group that was once related to p16/15 in fugu or zebrafish while p18/INKC and p19/INK4D are more closely related to corresponding orthologs in fugu. Figure 2 suggests that the complement of INK4 genes arose before the marsupial-placental mammal divergence.

During the evolution of p16/INK4A and p15/INK4B through gene duplication, an additional exon appeared when comparing the two genes. This alternative exon is designated exon $1 \beta$ which is alternatively spliced to exon 2 and 3 of p16INK4A making the novel p14ARF transcript (Figure 3) [37]. Previously, it was postulated that exon $1 \beta$ was the original exon 1 of the INK4A locus but later it was determined that this alternative exon was transcribed from its own separate promoter and not from the promoter of $\mathrm{p} 16 / \mathrm{INK} 4 \mathrm{~A}$ exon $1 \alpha$ [51]. The presence of such a separate promoter for p14ARF suggests that its transcription is regulated independently of p16/INK4A. Gene duplication, rearrangement and deletion appear to have resulted in a duplicated exon $1 \beta$ located in the intergenic region between the INK4A and B genes that later diverged from each other $[37,48]$. Interestingly, the highly cancer resistant naked mole rat has recently been shown to have an unusual fusion of the p15/p16 tumor suppressor genes (PMID: 25550505). This may represent a further gene rearrangement whose relationship to relative cancer resistance and unusually long life in this rodent remain to be investigated.

\subsection{Roles of INK4A/ARF Encoded Regulators in the Cell Cycle and Cancer}

The existence of p16/INK4A protein was first discovered as a binding partner of cyclin D-dependent CDK4 by the co-immunoprecipitation assay. In cells transformed by SV40 virus, CDK4 was found to be predominantly associated with p16 rather than cyclin D unraveling an important function of this founder member of the INK4 family and suggesting that p16 can directly bind to the catalytic CDK4 subunit in the absence of regulatory cyclin D [40]. Other INK4 members (p15, p18 and p19) were found to interact with CDK4 and CDK6 by two-hybrid screening. Both in vitro and in vivo studies have reported that all of the four INK4 proteins directly bind the kinase subunits $(C D K 4 / 6)$ rather than the cyclin subunit (cyclin D) as they act as competitive inhibitors of the cyclins [52]. This specific interaction with CDKs distinguishes the INK4 family from the Cip/Kip family of CKIs [36]. Because there is no sequence similarity between exon $1 \beta$ of p14ARF and exon $1 \alpha$ of p16 and alternative splicing of exon $1 \beta$ to the shared exon 2 allows translation to continue from the -1 nucleotide of the open reading frame of p16, p14ARF encodes a completely different protein compared to $\mathrm{p} 16$. These two proteins also function in distinct biological pathways. $\mathrm{Rb}$ is a critical substrate for cyclin D-dependent kinases [40,53] and its phosphorylation is required to release and activate the E2F transcription factors switching on gene expression involved in the G1 to $\mathrm{S}$ phase transition [54]. p16/INK4A and the three other INK4 members prevent Rb phosphorylation by inhibiting CDK4/6 binding with cyclin D [34,35]. This cascade pathway in turns leads to E2F repression that inhibits the transcription of many genes required for exit from G1 and initiation of $S$ phase eventually resulting in growth arrest $[37,54]$. 

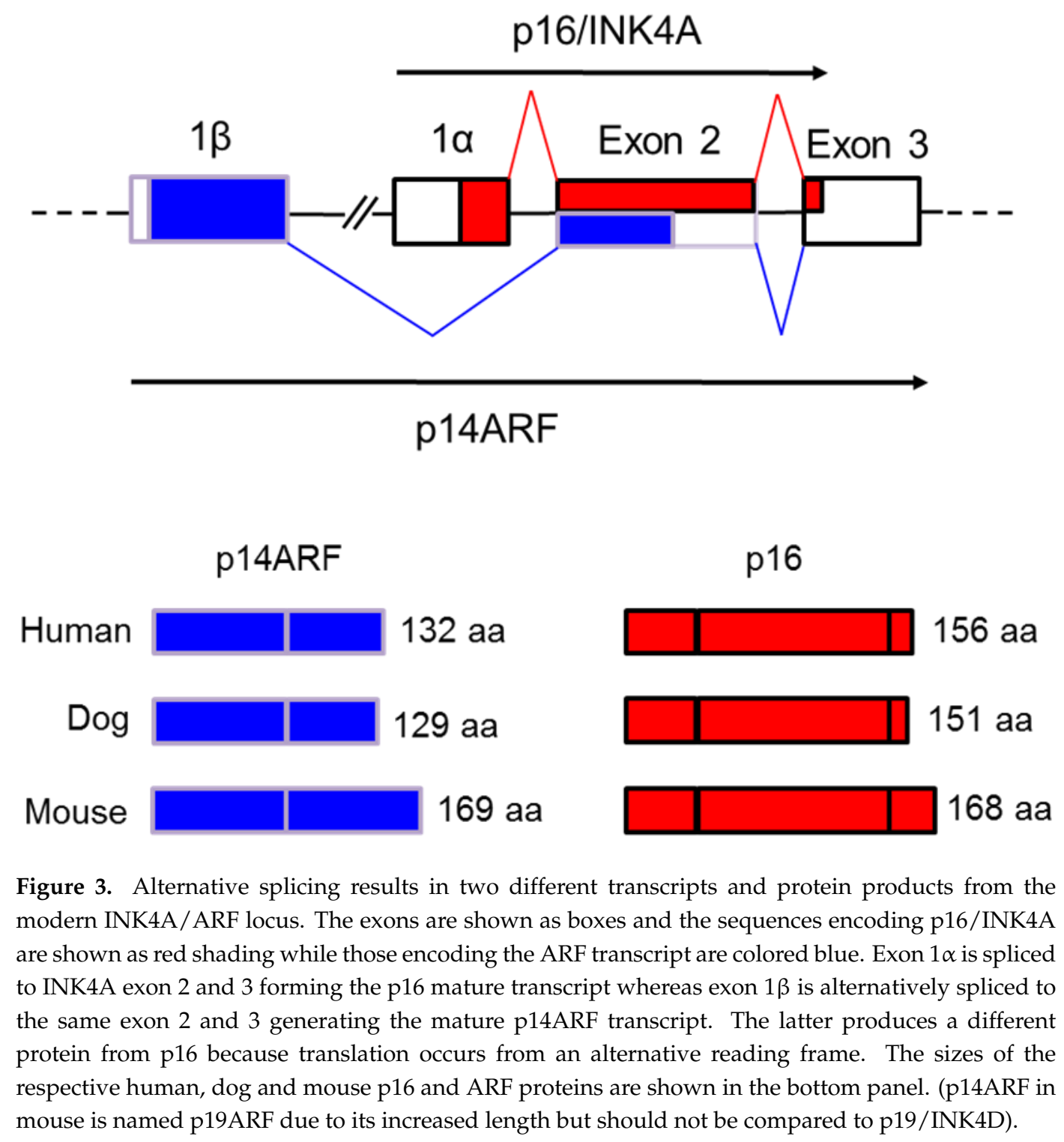

On the other hand, p14ARF is highly unlikely to act as a direct inhibitor of CDK4/6 because of its structural differences from other INK4 proteins. A great number of studies, using mouse models and human cancer cells, differentiated the functions and regulation of p14ARF from that of p16. The initial evidence for its anti-proliferative role came from observations that expression of p19ARF (the p14ARF ortholog in mouse) in embryonic fibroblasts or NIH 3T3 cells induced cell cycle arrest but no direct interaction with CDK complexes was detected in immunoprecipitation assays [55]. It has been reported that loss of p19ARF obviates the requirement of p53 inactivation to immortalize mouse embryonic fibroblasts and tumors, including melanomas, in vivo [56,57]. This understanding was further refined by other studies demonstrating that suppression of oncogenic transformation in primary cells by p19ARF is abrogated when p53 is inactivated by viral oncoproteins or dominant p53 mutants [58] implying that p19ARF functions upstream of the p53 pathway. Moreover, some groups reported that p19ARF can associate with MDM2 (a p53 ubiquitin protein ligase) or inhibit the E3-ligase activity of MDM2 to prevent MDM2-induced p53 degradation [57-61] suggesting that these proteins-p19ARF, MDM2 and p53 - exist in a common regulatory pathway. In addition to p53 stabilization, p14ARF regulates p53 transactivation activity. p53 normally acts as a strong transcriptional activator of $\mathrm{p} 21 / \mathrm{Cip} 1$ protein [38]. Expression of p19ARF in primary mouse cells expressing functional p53 results in the induction of p21 that plays essential roles in 
G1 to $S$ phase arrest, apoptosis and tumor growth suppression [57-59]. Investigating mutations and gene expression profiles of cell cycle regulatory proteins in many human cancer cell lines and primary tumors provided evidence that p53 mutations do not directly correlate with either p16 or $\mathrm{Rb}$ expression [30] stressing the fact that p14ARF (in the p53 pathway) and p16 (in the Rb pathway) have distinct or non-overlapping, important biological functions in cell cycle regulation and cancers [36,37]. Thus, this single locus capably regulates the key pathways controlling cell proliferation - the Rb-dependent and p53-dependent pathways.

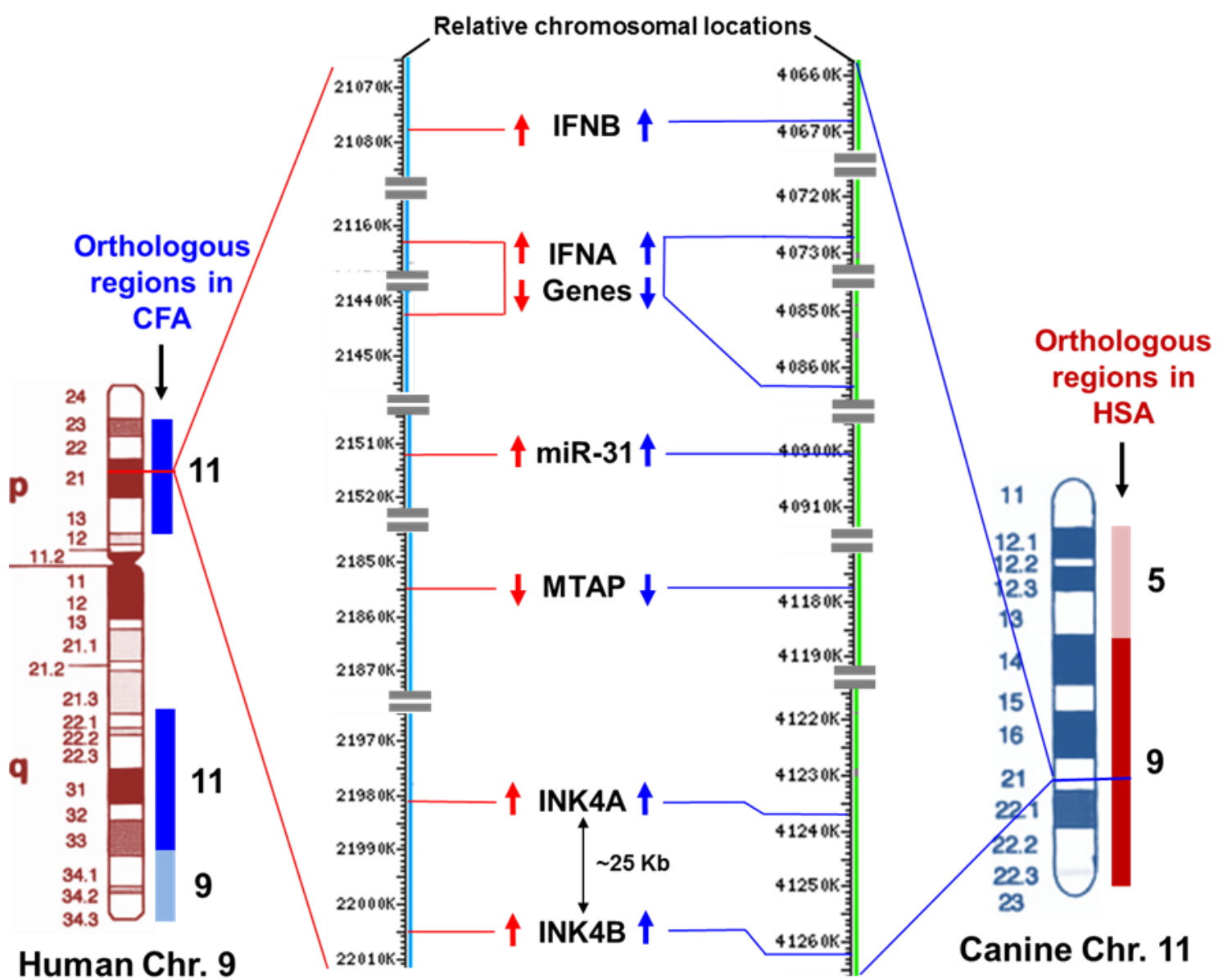

Frequently deleted regions in human chr. 9p21 and orthologous canine chr. 11

Figure 4. Relative molecular and cytogenetic mapping of the INKA/ARF locus and closely related genes with their positions on human and canine chromosome 9 and 11, respectively. The regions at human chromosome 9 and canine chromosome 11 that are frequently deleted in cancers are completely orthologous to each other. The molecular mapping shows the exact chromosomal position of these genes extrapolated from the NCBI map view of each chromosome represented by the current human and canine annotation from releases 106 and 103, respectively. The red and blue arrows indicate the transcriptional orientation of genes in the human and dog chromosomes, respectively. Transcription of genes from the "+ strand" is indicated by down arrows and from the "- strand" by up arrows. (CFA = Canis lupus familiaris; HSA = Homo sapiens; Chr. = Chromosome).

\subsection{Alteration of the INK4A/ARF Locus in Human and Canine Cancers}

There is compelling genetic evidence from numerous cancer studies that $\mathrm{p} 16 / \mathrm{INK} 4 \mathrm{~A}$ is a critical tumor suppressor gene whose direct inactivation by point mutation, deletion, or promoter hypermethylation is observed in nearly one third of human cancers, establishing its loss as one of the 
most frequent lesions promoting human malignancy [37]. The p16/INK4A gene was independently isolated as a candidate tumor suppressor gene located at human chromosome 9p21, the region which is highly conserved across mammals, and was found to be frequently deleted in many human tumors and linked to hereditary susceptibility to melanoma [60-62]. The emergence of human chromosome 9 p21 as a site of a major tumor suppressor gene was deduced from extensive cytogenetic and loss of heterozygosity $(\mathrm{LOH})$ studies on a wide range of tumors such as leukemias, melanomas, gliomas, pancreatic adenocarcinomas, as well as breast, lung and bladder cancers [61,63-68]. LOH of chromosome 9p21 that encodes the INK4/ARF locus was also deleted in the study of a neighboring gene called methylthioadenosine phosphorylase (MTAP) that also mapped to the same chromosomal region [69]. MTAP, a regulatory gene for purine and polyamine biosynthesis, is frequently deleted in different malignant cancer cell lines that also have homozygous deletion of p16 suggesting that loss of MTAP in malignant cells is primarily due to linkage between the MTAP and p16 genes on the same chromosomal region and so they were co-deleted [70]. Furthermore, some malignant cells were found to have homozygous deletion of p16 and MTAP but retained an intact p15 gene. These findings of homozygous deletion of p16 and its neighbor in cancer cells also revealed the gene order on chromosome 9p21 starting from the centromeric end which is p15, (p14ARF) p16, MTAP, IFNA and IFNB (interferon alpha and beta) (Figure 4) [70].

Studies with non-human animal models of cancers have also reported genetic defects in the INK4A/ARF locus. The in vivo role of p16 in tumorigenesis was initially indicated from mapping tumor susceptibility alleles in common BALB/c mouse strains. This mouse model is prone to tumor development such as plasmacytoma (tumors of the plasma cells) and lung adenocarcinoma in which the major genetic determinant responsible for a strong cancer predisposition also mapped to the INK4A/ARF locus [71,72]. Mice with targeted deletions of p16, p19ARF or both were investigated by several groups suggesting that mouse strains with specific inactivation of p16 or p19ARF were tumor prone but neither genetic loss alone was as severe as those with double knockouts of both of these genes [57,73-75]. Mutant mice that were deficient for p16 and heterozygous for p19ARF spontaneously develop a wide range of tumors including melanoma [95]. Importantly, primary melanomas, mammary carcinomas and osteosarcomas from dogs have also been reported to harbor frequent defects in p16/INK4A [21,45,46,76]. Altered expression profiles from p16/INK4A/ARF have been recurrently observed in a number of canine breast cancers, melanomas and other primary tumors that highly correlate to lesions in humans and mice $[30,37,77]$. In fact, altogether, deletions or point mutations causing shifting of reading frame and altered expression located mostly in exon $1 \alpha$ have been found in cancers from humans, dogs and mice suggesting that specific mutation mapping in p16/INK4A and its regulation are not limited to these cancer types (for example, melanomas and breast cancers) but also occur in other tumors commonly encountered in mammalian species with neoplasms or uncontrolled cellular growth $[21,71,72,77,78]$.

Furthermore, the region at canine chromosome 11 (orthologous to human chromosome 9p21) encoding INK4A/ARF, MTAP and close neighbors including miR-31, as shown in the comparative chromosomal mapping (Figure 4), is also highly susceptible and prone to concomitant deletion in many cancers in dogs [16]. Reports from several studies suggested that a haplotype spanning MTAP and INK4A/ARF loci showed susceptibility to naturally occurring canine sarcomas [79]. The miR-31, one of the highly cited tumor suppressor miRNAs in human breast cancer, was also found to be down-regulated and differentially expressed in canine osteosarcoma and mammary tumors, respectively [80]. Therefore, the comparative analysis of cytogenetic and molecular mapping of the genetic defects at human chromosome 9p21 and the corresponding canine chromosome 11 identified frequently deleted regions encoded by the INK4A/ARF/INK4B locus with a highly conserved order of genes (Figure 4) that are concurrently lost in many cancers recapitulating the strong similarities in genetic alternations and cancer predisposition between humans and dogs. 


\section{Regulatory, Small Non-Coding RNAs: microRNAs in Cancers}

It is increasingly apparent that a significant portion of the mammalian genome (estimated to be $>70 \%$ ) encodes regulatory information that is largely carried out by non-coding RNAs [81-83]. These non-coding RNAs consist of two major classes: small non-coding RNAs ( $<200 \mathrm{bp}$, including miRNAs) and long noncoding RNAs or lncRNAs (>200 to $\sim 100 \mathrm{~kb}$ ) [84,85]. IncRNAs share many features of mRNAs, but in contrast to mRNAs, they are found within introns of protein coding genes or intergenic regions of the genome [83] demonstrating developmental and tissue-specific expression patterns [86]. The lncRNAs play a number of important regulatory functions that affect epigenetic changes including chromatin remodeling, transcriptional co-activation and repression, post-transcriptional modification of mRNAs as well as cellular functions including differentiation and homeostasis [84]. Dysregulated expression of lncRNAs causes disruption of these biological functions and plays a critical role in cancer development [85]. To date, a number of lncRNAs have been implicated in breast cancer development and metastasis. One of the most well-known and first identified lncRNAs is a HOX antisense intergenic RNA that is commonly abbreviated as HOTAIR. This lncRNA, located in the mammalian HOXC locus, has been demonstrated to be associated with polycomb repressive complex 2 that mediates transcriptional repression of numerous genes involved in differentiation pathways during development and stem cell pluripotency [87-90]. Importantly, HOTAIR has been reported to be highly upregulated in both primary and metastatic breast cancers and its overexpression is a strong predictor of metastasis and poor survival [87]. However, unlike the rapid advances in miRNA research, including the well-established mechanisms of miRNAs in gene silencing and the strong sequence conservation of miRNAs across mammals, knowledge regarding the molecular mechanisms of lncRNA function in cancer is still growing. Most lncRNAs are poorly conserved, and their mechanisms of action remain unclear and are in need of further exploration $[83,84]$.

The discovery of microRNAs (miRNAs) established a new era in translational regulation research and for understanding post-transcriptional regulation of genes as well as their critical regulatory roles in diverse biological processes including cell cycle, cell proliferation, differentiation, development and apoptosis as well as in disease pathogenesis [91-93]. miRNAs are evolutionarily conserved, endogenous small structural RNA molecules ( 22 nucleotides) that post-transcriptionally suppress gene expression in a sequence specific manner [94]. Expression of these small structural RNAs is tightly regulated during development and in normal mature tissues and is frequently altered in cancer [95]. Strikingly, more than 50\% of miRNA genes are located in cancer associated genomic regions or fragile sites that are also preferential sites for translocation, deletion, amplification, and integration of exogenous genome fragments suggesting that miRNAs play an important role in the pathogenesis of many human cancers [96,97]. Since miRNAs are encoded by highly conserved and naturally occurring genes across mammalian species, evaluation of their expression profiles in cancer models shows great promise for advancing the development of future therapeutic reagents, as well as for improving diagnostic and prognostic analysis.

miRNAs and their associated proteins appear to be one of the most abundant biomolecules in the cell. Improvements in small nucleotide amplification technologies and in sequence prediction algorithms, miRNA discovery from model organisms, as well as non-model species, have greatly advanced with 35,828 mature miRNAs in 223 species putatively identified to date (miRBase v20.0). Based on this latest estimate, the human, mouse and canine genomes account for 2588, 1915 and 453 mature miRNAs, respectively, and these numbers reflect those miRNAs identified to date and this is anticipated to grow to similar numbers in most mammals compared to the human genome. The number of experimentally validated miRNAs from each species is smaller than the predicted number. However, both bioinformatics and empirical evidence suggests that more than $30 \%$ of protein-coding genes in the human genome are subjected to regulation by miRNAs, indicating their prominence as global regulators of gene expression [98-101]. 
In mammals, mature miRNAs generated from sequential processing of primary miRNA transcripts by Drosha and Dicer miRNA processing complexes associate with $3^{\prime}$ untranslated regions ( $3^{\prime}$ UTR) of specific target messenger RNAs (mRNAs) to suppress translation and may also induce their degradation [102]. In the nucleus, the RNase III-type enzyme Drosha processes the long primary transcripts (pri-miRNA that is initially transcribed by RNA polymerase II from the cellular genome), yielding 60-70 nucleotide hairpin precursors called pre-miRNA. The resulting pre-miRNA hairpins are translocated to the cytoplasm by Exportin-5. In the cytoplasm, the pre-miRNAs are further cleaved and processed into 19-25 nucleotide miRNA duplex structures by the RNase Dicer and transactivator RNA binding protein (TRBP). The functional strand (or guide strand) of the mature miRNA is loaded together with Argonaut (Ago2) proteins into an RNA-induced silencing complex (RISC), where it guides RISC to silence target mRNAs through mRNA cleavage, translational repression or deadenylation. The passenger strand (the complementary strand of the double stranded pre-miRNA following Dicer processing) is typically degraded [102]. The mature miRNAs usually target the $3^{\prime}$ UTR of mRNAs and make complementary base pairing with their seed (core orthologous target) sequences (located at $2-8$ bases from the $5^{\prime}$ end of the miRNA) [97]. The seed sequence, by which miRNAs bind to their targets, is only several nucleotides long, suggesting that each miRNA may potentially bind to a large number of genes thereby regulating their expression. miRNAs can direct the RISC complex to downregulate target gene expression by either of two post-transcriptional mechanisms: mRNA cleavage or translational repression $[98,103,104]$. The execution of one of these mechanisms is primarily determined by the degree of complementarity between the miRNA and its target mRNA. The miRNA will promote the cleavage of the target message if its seed region is sufficiently complementary to the target sequences [105]. After degradation of the mRNA, the miRNA remains intact and can guide the RISC to target other messages. Interestingly, miRNAs can regulate their own expression or biosynthesis by targeting the miRNA processing machinery. For example, the miR-103/107 family can inhibit DICER expression and induce epithelial to mesenchymal transition (EMT) promoting metastasis in human breast cancer [106].

\subsection{OncomiRs: Cancer Associated miRNAs}

The association of miRNAs with the initiation, progression and key control pathways of human malignancies holds great potential for new developments in advanced diagnostic and therapeutic strategies in the management of most common cancers. The expression of miRNAs are deregulated in cancer by a variety of mechanisms including amplification, deletion, mutation or epigenetic silencing [107-109]. Epigenetic regulation of miRNAs is mediated by promoter hypermethylation in certain human cancers. For example, miR-127, which is downregulated in human cancer cells, has been reported to be located within a CPG island and highly up-regulated by DNA demethylation and histone acetylation [109]. Many groups have discovered "miRNA signatures" in both hematological and solid tumors that discriminate cancers from normal cells and have potential for improving prognosis, management of progression and possibly suppression of cancer [97,110-114]. miRNAs are often regarded as "oncomiRs" meaning miRNAs involved in dominant cancer regulatory mechanisms. OncomiRs can be categorized as tumor oncogenes and tumor suppressors as anti-oncomiRs. miR-155 was one of the first identified oncomiRs that has been demonstrated to be highly expressed in several well-known lymphomas, leukemias, breast, colon and lung cancers [111,113-116]. Like miR-155, other oncogenic miRNAs usually target tumor suppressor genes and cell cycle inhibitors, or other anti-proliferative genes and they can also serve as potential therapeutic targets. Another strong oncogenic candidate miRNA is miR-21 which is upregulated in a wide variety of blood related and solid tumors including myeloid leukemia, lymphocytic leukemia, gliobalstoma and cancers of the pancreas, prostate, stomach, colon, lung, liver and breast $[110,113,117-119]$. Overexpression of miR-21 in these cancers inhibits the apoptotic pathway promoting dysregulated cell proliferation. miR-21 was also one of the first miRNAs identified in the human genome that showed strong evolutionary conservation across a wide range 
of vertebrate species. Three major targets of miR-21 include prominent tumor suppressors such as PTEN (phosphatase and tensin homolog), an important regulator of cardiovascular disease, PDCD4 (programmed cell death 4) and TPM1 (tropomyosin 1) [119-122].

The let-7 miRNA was one of the first anti-oncomiRs, or tumor suppressor miRNAs, characterized, which is highly conserved among mammalian species, and is downregulated in many tumors including lung and breast cancers $[111,114,123]$. The let-7 miRNA family functionally inhibits a number of well-characterized oncogenes such as ras, c-myc and HMGA2 and induces apoptosis and cell cycle arrest in human colon cancer cells [123-126]. This miRNA targets the ras oncogene in lung cancer by being abnormally under-expressed promoting cell cycle progression [123]. In addition, let-7 also downregulates the expression of c-myc, a transcriptional activator of many tumor promoting genes that are dysregulated in lymphomas. Thus, anti-oncomiRs effectively control the expression of many oncogenes and their transcription factors at a post-transcriptional level.

\subsection{Regulation of miRNAs in Human and Canine Breast Cancers}

The association between altered miRNA expression signatures and breast cancer metastasis has been described by many studies $[127,128]$. A large number of miRNAs have been identified as deregulated in human breast cancer compared to normal breast tissue. The overexpression of certain oncogenic miRNAs (miR-21, miR-27a, miR-155, miR-9, miR-10b, miR-373/miR-520c, miR-206, $\mathrm{miR}-18 \mathrm{a} / \mathrm{b}$, miR-221/222) and the loss of several tumor suppressor miRNAs (miR-205/200, miR-125a, miR-125b, miR-126, miR-17-5p, miR-145, miR-200c, let-7, miR-20b, miR-34a, miR-31, miR-30) lead to loss of regulation of vital cellular functions that are involved in breast cancer pathogenesis $[127,128]$. In human breast cancer, miR-21 upregulates the EMT, the PI3K/ATK signaling pathway, the anti-apoptotic pathway and induces proliferation by targeting very well-characterized tumors suppressors such as PTEN, TPM1, and PDCD4 $[121,122,129,130]$. Strikingly, all of these miR-21 targets have been reported to be deregulated in canine mammary tumors as well. In this regard, expression of selected miRNAs associated with human breast cancers have been investigated in canine malignant mammary tumors. Almost all of the canine miRNAs in CMTs followed the same expression profile observed in human breast cancers when compared to normal canine mammary tissue. This investigation revealed that miR-21 and miR-29b were significantly up-regulated and miR-15b, miR-16 were significantly down-regulated in breast cancers in both species [131].

\section{3. miRNAs Regulate Cell Cycle by Targeting Multiple Genes}

An important function of miRNAs is to regulate cell cycle progression and arrest by targeting multiple cell cycle regulatory genes. These miRNAs regulate cell proliferation by specifically targeting cyclin-CDK complexes and CDK inhibitors. One of the first discoveries that connected miRNAs and cell cycle regulation was the anti-proliferative potential of the miR-15a/16-1 family that target multiple cell cycle genes involved in cellular proliferation and growth arrest [132-135]. The miR-16 family act as tumor suppressors that induce cell cycle arrest at the G1 phase by targeting several cyclin-CDK genes including CDK6, cyclin D1, cyclin D3, E2F3 and WEE1 and all the miRNAs in this family are downregulated in a wide variety of tumors [136]. Additionally, miR-34 and other family members, target CDK4/6, cyclin D1, cyclin E2, E2F1/3 and c-myc, indicating their strong anti-proliferative roles [137]. These miRNAs are transcriptionally activated by p53 and are involved in the p53 signaling pathway thereby acting as mediators of tumor growth suppression [138]. However, the tumor suppressive miRNAs involved in cell cycle regulation are inactivated in tumors by epigenetic mechanisms, such as hypermethylation, leading to overexpression of their target genes [139]. For example, members of the miR-290 family positively regulate G1 to S phase transition by inhibiting cyclin-dependent kinase inhibitors such as p21, during embryonic stem cell differentiation [140]. The Cip/Kip family CKIs are targeted by miR-17-92, miR-106b, the miR-221 family and miR-25 in many different carcinomas [136]. Expression of p16/INK4A is repressed by miR-24 and miR-31 which are also involved in the regulation of cell proliferation and progression 
of cell cycle in many cancers [141,142]. It has been reported that miR-21 negatively regulates cell cycle during G1 to $S$ phase transition in response to DNA damage and inhibits Cdc25A expression affecting G2/M progression in colon cancer cells [143]. Another study showed that miR-322/424 and miR-503 are upregulated during myogenesis and these miRNAs promote cell cycle arrest at G1 phase by down-regulating Cdc25A [144]. A recent report revealed that canine miR-141 can post-transcriptionally regulate p16/INK4A and p14ARF transcripts while groups of differentially expressed miRNAs may potentially target the rest of the CKI gene family members as well as oncogenes of the cell cycle in canine breast cancer models [145]. All of these reports clearly suggest that the cell cycle G1 to $S$ phase transition is tightly regulated by several families of miRNAs. Therefore, different miRNAs regulate the cell cycle both positively and negatively by targeting the expression of many genes at different stages, and dysregulation of most of these regulatory molecules and pathways have been implicated in different pathological or developmental conditions.

\section{Conclusions}

In conclusion, the strong similarities in genome sequence, along with highly similar characteristics for spontaneous tumor models, have raised great promise for further comparative genomic research between humans and dogs. Comparing spontaneous mammary carcinomas in female dogs with breast cancer in women has significantly improved our understanding in deciphering the molecular mechanisms, relevant risk factors, and genetic profiles of these types of cancer and as well as novel strategies for future therapeutic inventions. However, although there is great potential in canine cancer models, a large number and complete interactions of cancer associated genes such as the cell cycle regulators, including the INK4 tumor suppressor genes and emerging miRNAs in the canine genome, have not been well studied in such models. Additionally, the high correlation between tumor suppressor gene expression and miRNA activity imposing post-transcriptional regulation is one of the central areas in cancer research which also needs to be further explored.

Acknowledgments: The authors (RCB and FMLK) thank AURIC (Auburn University Research Initiative in Cancer) for research and scholarship (FMLK) funding. CEA was supported by Department of Defense CDMRP award no. W81XWH-11-2-0224, American Kennel Club CHF award no. 01660, and Morris Animal Foundation award no. D13CA-073.

Author Contributions: Farruk M. Lutful Kabir and R. Curtis Bird worked together to develop the ideas presented in this review which has grown out of the doctoral training program of Luful Kabir. Specifically, Luful Kabir was a trainee in Bird's program developing these ideas as part of his training in full collaboration with Bird. Both authors contributed to the writing and editing of the manuscript. Carlos E. Alvarez provided in depth analysis of the genomes presented as well as the bioinformatics analysis and contributed to the editing of the manuscript as well.

Conflicts of Interest: The authors declare no conflict of interest.

\section{References}

1. Rowell, J.L.; McCarthy, D.O.; Alvarez, C.E. Dog models of naturally occurring cancer. Trends Mol. Med. 2011, 17, 380-388. [CrossRef] [PubMed]

2. Smith, B.F.; Bird, R.C. Hematologic neoplasia-Gene therapy. In Schalm's Veterinary Hematology; Weiss, D.J., Wardrop, K.J., Eds.; Wiley-Blackwell: Iowa City, IA, USA, 2010; pp. 550-557.

3. American Veterinary Medical Association. Us Pet Ownership and Demographics Sourcebook 2007; American Veterinary Medical Association: Schaumburg, IL, USA, 2008.

4. Lindblad-Toh, K.; Wade, C.M.; Mikkelsen, T.S.; Karlsson, E.K.; Jaffe, D.B.; Kamal, M.; Clamp, M.; Chang, J.L.; Kulbokas, E.J., 3rd; Zody, M.C.; et al. Genome sequence, comparative analysis and haplotype structure of the domestic dog. Nature 2005, 438, 803-819. [CrossRef] [PubMed]

5. Khanna, C.; Lindblad-Toh, K.; Vail, D.; London, C.; Bergman, P.; Barber, L.; Breen, M.; Kitchell, B.; McNeil, E.; Modiano, J.F.; et al. The dog as a cancer model. Nat. Biotechnol. 2006, 24, 1065-1066. [CrossRef] [PubMed] 
6. Vail, D.M.; MacEwen, E.G. Spontaneously occurring tumors of companion animals as models for human cancer. Cancer Investig. 2000, 18, 781-792. [CrossRef]

7. Cullen, J.M.; Page, R.; Misdorp, W. An overview of cancer pathogenesis, diagnosis and management. In Tumors in Domestic Animals; Moulton, D.J., Ed.; Blackwell Publishing Company, Iowa State Press: Ames, IA, USA, 2002; pp. 3-45.

8. Jemal, A.; Siegel, R.; Ward, E.; Murray, T.; Xu, J.; Thun, M.J. Cancer statistics, 2007. CA 2007, 57, 43-66. [CrossRef] [PubMed]

9. Owen, L.N. A comparative study of canine and human breast cancer. Investig. Cell Pathol. 1979, 2, $257-275$.

10. Sorenmo, K. Canine mammary gland tumors. Vet. Clin. North Am. Small Anim. Pract. 2003, 33, 573-596. [CrossRef]

11. Ahern, T.E.; Bird, R.C.; Bird, A.E.; Wolfe, L.G. Expression of the oncogene c-erbb-2 in canine mammary cancers and tumor-derived cell lines. Am. J. Vet. Res. 1996, 57, 693-696. [PubMed]

12. Misdorp, W. Tumors of the mammary gland. In Tumors in Domestic Animals; Meuten, D.J., Ed.; Iowa State Press: Ames, IA, USA, 2002; pp. 575-606.

13. Sleeckx, N.; de Rooster, H.; Veldhuis Kroeze, E.J.; Van Ginneken, C.; Van Brantegem, L. Canine mammary tumours, an overview. Reprod. Domest. Anim. 2011, 46, 1112-1131. [CrossRef] [PubMed]

14. Shinoda, H.; Legare, M.E.; Mason, G.L.; Berkbigler, J.L.; Afzali, M.F.; Flint, A.F.; Hanneman, W.H. Significance of eralpha, her2, and cav1 expression and molecular subtype classification to canine mammary gland tumor. J. Vet. Diagn. Investig. 2014, 26, 390-403. [CrossRef] [PubMed]

15. Gama, A.; Alves, A.; Schmitt, F. Identification of molecular phenotypes in canine mammary carcinomas with clinical implications: Application of the human classification. Virchows Arch. 2008, 453, 123-132. [CrossRef] [PubMed]

16. Beck, J.; Hennecke, S.; Bornemann-Kolatzki, K.; Urnovitz, H.B.; Neumann, S.; Strobel, P.; Kaup, F.J.; Brenig, B.; Schutz, E. Genome aberrations in canine mammary carcinomas and their detection in cell-free plasma DNA. PLoS ONE 2013, 8, e75485. [CrossRef] [PubMed]

17. Sassi, F.; Benazzi, C.; Castellani, G.; Sarli, G. Molecular-based tumour subtypes of canine mammary carcinomas assessed by immunohistochemistry. BMC Vet. Res. 2010, 6, 5. [CrossRef] [PubMed]

18. Lutful Kabir, F.M.; DeInnocentes, P.; Agarwal, P.; Riese, D.J.; Bird, R.C. Estrogen receptor-alpha, progesterone receptor and c-erbb/her-family receptor mrna detection and phenotype analysis in spontaneous canine models of breast cancer. Vet. Pathol. 2015, in preparation.

19. Uva, P.; Aurisicchio, L.; Watters, J.; Loboda, A.; Kulkarni, A.; Castle, J.; Palombo, F.; Viti, V.; Mesiti, G.; Zappulli, V.; et al. Comparative expression pathway analysis of human and canine mammary tumors. BMC Genom. 2009, 10, 135. [CrossRef] [PubMed]

20. Rao, N.A.; van Wolferen, M.E.; van den Ham, R.; van Leenen, D.; Groot Koerkamp, M.J.; Holstege, F.C.; Mol, J.A. Cdna microarray profiles of canine mammary tumour cell lines reveal deregulated pathways pertaining to their phenotype. Anim. Genet. 2008, 39, 333-345. [CrossRef] [PubMed]

21. Lutful Kabir, F.M.; Agarwal, P.; Deinnocentes, P.; Zaman, J.; Bird, A.C.; Bird, R.C. Novel frameshift mutation in the p16/ink4a tumor suppressor gene in canine breast cancer alters expression from the p16/ink4a/p14arf locus. J. Cell. Biochem. 2013, 114, 56-66. [CrossRef] [PubMed]

22. Klopfleisch, R.; Gruber, A.D. Differential expression of cell cycle regulators p21, p27 and p53 in metastasizing canine mammary adenocarcinomas versus normal mammary glands. Res. Vet. Sci. 2009, 87, 91-96. [CrossRef] [PubMed]

23. Van ‘t Veer, L.J.; Dai, H.; van de Vijver, M.J.; He, Y.D.; Hart, A.A.; Mao, M.; Peterse, H.L.; van der Kooy, K.; Marton, M.J.; Witteveen, A.T.; et al. Gene expression profiling predicts clinical outcome of breast cancer. Nature 2002, 415, 530-536. [CrossRef] [PubMed]

24. Saal, L.H.; Johansson, P.; Holm, K.; Gruvberger-Saal, S.K.; She, Q.B.; Maurer, M.; Koujak, S.; Ferrando, A.A.; Malmstrom, P.; Memeo, L.; et al. Poor prognosis in carcinoma is associated with a gene expression signature of aberrant pten tumor suppressor pathway activity. Proc. Natl. Acad. Sci. USA 2007, 104, 7564-7569. [CrossRef] [PubMed]

25. Sweet-Cordero, A.; Mukherjee, S.; Subramanian, A.; You, H.; Roix, J.J.; Ladd-Acosta, C.; Mesirov, J.; Golub, T.R.; Jacks, T. An oncogenic kras2 expression signature identified by cross-species gene-expression analysis. Nat. Genet. 2005, 37, 48-55. [CrossRef] [PubMed] 
26. Hanahan, D.; Weinberg, R.A. Hallmarks of cancer: The next generation. Cell 2011, 144, 646-674. [CrossRef] [PubMed]

27. Pines, J.; Hunter, T. Cyclin-dependent kinases: A new cell cycle motif? Trends Cell Biol. 1991, 1, 117-121. [CrossRef]

28. Mareel, M.; Leroy, A. Clinical, cellular, and molecular aspects of cancer invasion. Physiol. Rev. 2003, 83, 337-376. [CrossRef] [PubMed]

29. Sherr, C.J. Cancer cell cycles. Science 1996, 274, 1672-1677. [CrossRef] [PubMed]

30. Okamoto, A.; Demetrick, D.J.; Spillare, E.A.; Hagiwara, K.; Hussain, S.P.; Bennett, W.P.; Forrester, K.; Gerwin, B.; Serrano, M.; Beach, D.H.; et al. Mutations and altered expression of p16ink4 in human cancer. Proc. Natl. Acad. Sci. USA 1994, 91, 11045-11049. [CrossRef] [PubMed]

31. Otterson, G.A.; Kratzke, R.A.; Coxon, A.; Kim, Y.W.; Kaye, F.J. Absence of p16ink4 protein is restricted to the subset of lung cancer lines that retains wildtype rb. Oncogene 1994, 9, 3375-3378. [PubMed]

32. Harper, J.W.; Elledge, S.J. Cdk inhibitors in development and cancer. Curr. Opin. Genet. Dev. 1996, 6, 56-64. [CrossRef]

33. Vidal, A.; Koff, A. Cell-cycle inhibitors: Three families united by a common cause. Gene 2000, 247, 1-15. [CrossRef]

34. McConnell, B.B.; Gregory, F.J.; Stott, F.J.; Hara, E.; Peters, G. Induced expression of p16(ink4a) inhibits both cdk4- and cdk2-associated kinase activity by reassortment of cyclin-cdk-inhibitor complexes. Mol. Cell. Biol. 1999, 19, 1981-1989. [CrossRef] [PubMed]

35. Parry, D.; Mahony, D.; Wills, K.; Lees, E. Cyclin d-cdk subunit arrangement is dependent on the availability of competing ink4 and p21 class inhibitors. Mol. Cell. Biol. 1999, 19, 1775-1783. [CrossRef] [PubMed]

36. Ruas, M.; Peters, G. The p16ink4a/cdkn2a tumor suppressor and its relatives. Biochim. Biophys. Acta 1998, 1378, F115-F177. [CrossRef]

37. Sharpless, N.E. Ink4a/arf: A multifunctional tumor suppressor locus. Mutat. Res. 2005, 576, $22-38$. [CrossRef] [PubMed]

38. Sharpless, N.E.; DePinho, R.A. The ink4a/arf locus and its two gene products. Curr. Opin. Genet. Dev. 1999, 9, 22-30. [CrossRef]

39. Xiong, Y.; Hannon, G.J.; Zhang, H.; Casso, D.; Kobayashi, R.; Beach, D. P21 is a universal inhibitor of cyclin kinases. Nature 1993, 366, 701-704. [CrossRef] [PubMed]

40. Hunter, T.; Pines, J. Cyclins and cancer. Ii: Cyclin d and cdk inhibitors come of age. Cell 1994, 79, 573-582. [CrossRef]

41. Kamb, A.; Gruis, N.A.; Weaver-Feldhaus, J.; Liu, Q.; Harshman, K.; Tavtigian, S.V.; Stockert, E.; Day, R.S., 3rd; Johnson, B.E.; Skolnick, M.H. A cell cycle regulator potentially involved in genesis of many tumor types. Science 1994, 264, 436-440. [CrossRef] [PubMed]

42. Wesierska-Gadek, J.; Schmid, G. Dual action of the inhibitors of cyclin-dependent kinases: Targeting of the cell-cycle progression and activation of wild-type p53 protein. Expert Opin. Investig. Drugs 2006, 15, 23-38. [CrossRef] [PubMed]

43. Serrano, M. The ink4a/arf locus in murine tumorigenesis. Carcinogenesis 2000, 21, 865-869. [CrossRef] [PubMed]

44. Aguirre-Hernandez, J.; Milne, B.S.; Queen, C.; O’Brien, P.C.; Hoather, T.; Haugland, S.; Ferguson-Smith, M.A.; Dobson, J.M.; Sargan, D.R. Disruption of chromosome 11 in canine fibrosarcomas highlights an unusual variability of cdkn2b in dogs. BMC Vet. Res. 2009, 5, 27. [CrossRef] [PubMed]

45. DeInnocentes, P.; Agarwal, P.; Bird, R.C. Phenotype-rescue of cyclin-dependent kinase inhibitor p16/ink4a defects in a spontaneous canine cell model of breast cancer. J. Cell. Biochem. 2009, 106, 491-505. [CrossRef] [PubMed]

46. Koenig, A.; Bianco, S.R.; Fosmire, S.; Wojcieszyn, J.; Modiano, J.F. Expression and significance of p53, rb, p21/waf-1, p16/ink-4a, and pten tumor suppressors in canine melanoma. Vet. Pathol. 2002, 39, 458-472. [CrossRef] [PubMed]

47. Migone, F.; Deinnocentes, P.; Smith, B.F.; Bird, R.C. Alterations in cdk1 expression and nuclear/nucleolar localization following induction in a spontaneous canine mammary cancer model. J. Cell. Biochem. 2006, 98, 504-518. [CrossRef] [PubMed]

48. Gilley, J.; Fried, M. One ink4 gene and no arf at the fugu equivalent of the human ink4a/arf/ink4b tumour suppressor locus. Oncogene 2001, 20, 7447-7452. [CrossRef] [PubMed] 
49. Byeon, I.J.; Li, J.; Ericson, K.; Selby, T.L.; Tevelev, A.; Kim, H.J.; O’Maille, P.; Tsai, M.D. Tumor suppressor p16ink4a: Determination of solution structure and analyses of its interaction with cyclin-dependent kinase 4. Mol. Cell 1998, 1, 421-431. [CrossRef]

50. Venkataramani, R.; Swaminathan, K.; Marmorstein, R. Crystal structure of the cdk4/6 inhibitory protein p18ink4c provides insights into ankyrin-like repeat structure/function and tumor-derived p16ink4 mutations. Nat. Struct. Biol. 1998, 5, 74-81. [CrossRef] [PubMed]

51. Mao, L.; Merlo, A.; Bedi, G.; Shapiro, G.I.; Edwards, C.D.; Rollins, B.J.; Sidransky, D. A novel p16ink4a transcript. Cancer Res. 1995, 55, 2995-2997. [PubMed]

52. Guan, K.L.; Jenkins, C.W.; Li, Y.; O’Keefe, C.L.; Noh, S.; Wu, X.; Zariwala, M.; Matera, A.G.; Xiong, Y. Isolation and characterization of p19ink4d, a p16-related inhibitor specific to cdk6 and cdk4. Mol. Biol. Cell 1996, 7, 57-70. [CrossRef] [PubMed]

53. Sherr, C.J. G1 phase progression: Cycling on cue. Cell 1994, 79, 551-555. [CrossRef]

54. Weinberg, R.A. The retinoblastoma protein and cell cycle control. Cell 1995, 81, 323-330. [CrossRef]

55. Quelle, D.E.; Ashmun, R.A.; Hannon, G.J.; Rehberger, P.A.; Trono, D.; Richter, K.H.; Walker, C.; Beach, D.; Sherr, C.J.; Serrano, M. Cloning and characterization of murine p16ink4a and p15ink4b genes. Oncogene 1995, 11, 635-645. [PubMed]

56. Chin, L.; Pomerantz, J.; Polsky, D.; Jacobson, M.; Cohen, C.; Cordon-Cardo, C.; Horner, J.W., 2nd; DePinho, R.A. Cooperative effects of ink4a and ras in melanoma susceptibility in vivo. Genes Dev. 1997, 11, 2822-2834. [CrossRef] [PubMed]

57. Kamijo, T.; Zindy, F.; Roussel, M.F.; Quelle, D.E.; Downing, J.R.; Ashmun, R.A.; Grosveld, G.; Sherr, C.J. Tumor suppression at the mouse ink4a locus mediated by the alternative reading frame product p19arf. Cell 1997, 91, 649-659. [CrossRef]

58. Pomerantz, J.; Schreiber-Agus, N.; Liegeois, N.J.; Silverman, A.; Alland, L.; Chin, L.; Potes, J.; Chen, K.; Orlow, I.; Lee, H.W.; et al. The ink4a tumor suppressor gene product, p19arf, interacts with mdm2 and neutralizes mdm2's inhibition of p53. Cell 1998, 92, 713-723. [CrossRef]

59. Kamijo, T.; Weber, J.D.; Zambetti, G.; Zindy, F.; Roussel, M.F.; Sherr, C.J. Functional and physical interactions of the ARF tumor suppressor with p53 and Mdm2. Proc. Natl. Acad. Sci. USA 1998, 95, 8292-8297. [CrossRef] [PubMed]

60. Hussussian, C.J.; Struewing, J.P.; Goldstein, A.M.; Higgins, P.A.; Ally, D.S.; Sheahan, M.D.; Clark, W.H., Jr.; Tucker, M.A.; Dracopoli, N.C. Germline p16 mutations in familial melanoma. Nat. Genet. 1994, 8, 15-21. [CrossRef] [PubMed]

61. Kamb, A.; Shattuck-Eidens, D.; Eeles, R.; Liu, Q.; Gruis, N.A.; Ding, W.; Hussey, C.; Tran, T.; Miki, Y.; Weaver-Feldhaus, J.; et al. Analysis of the p16 gene (cdkn2) as a candidate for the chromosome 9p melanoma susceptibility locus. Nat. Genet. 1994, 8, 23-26. [CrossRef] [PubMed]

62. Ranade, K.; Hussussian, C.J.; Sikorski, R.S.; Varmus, H.E.; Goldstein, A.M.; Tucker, M.A.; Serrano, M.; Hannon, G.J.; Beach, D.; Dracopoli, N.C. Mutations associated with familial melanoma impair p16ink4 function. Nat. Genet. 1995, 10, 114-116. [CrossRef] [PubMed]

63. Caldas, C.; Hahn, S.A.; da Costa, L.T.; Redston, M.S.; Schutte, M.; Seymour, A.B.; Weinstein, C.L.; Hruban, R.H.; Yeo, C.J.; Kern, S.E. Frequent somatic mutations and homozygous deletions of the p16 (mts1) gene in pancreatic adenocarcinoma. Nat. Genet. 1994, 8, 27-32. [CrossRef] [PubMed]

64. Dreyling, M.H.; Bohlander, S.K.; Adeyanju, M.O.; Olopade, O.I. Detection of cdkn2 deletions in tumor cell lines and primary glioma by interphase fluorescence in situ hybridization. Cancer Res. 1995, 55, 984-988. [PubMed]

65. Hatta, Y.; Hirama, T.; Miller, C.W.; Yamada, Y.; Tomonaga, M.; Koeffler, H.P. Homozygous deletions of the p15 (mts2) and p16 (cdkn2/mts1) genes in adult t-cell leukemia. Blood 1995, 85, 2699-2704. [PubMed]

66. Nobori, T.; Miura, K.; Wu, D.J.; Lois, A.; Takabayashi, K.; Carson, D.A. Deletions of the cyclin-dependent kinase-4 inhibitor gene in multiple human cancers. Nature 1994, 368, 753-756. [CrossRef] [PubMed]

67. Ogawa, S.; Hirano, N.; Sato, N.; Takahashi, T.; Hangaishi, A.; Tanaka, K.; Kurokawa, M.; Tanaka, T.; Mitani, K.; Yazaki, Y.; et al. Homozygous loss of the cyclin-dependent kinase 4-inhibitor (p16) gene in human leukemias. Blood 1994, 84, 2431-2435. [PubMed]

68. Quesnel, B.; Preudhomme, C.; Philippe, N.; Vanrumbeke, M.; Dervite, I.; Lai, J.L.; Bauters, F.; Wattel, E.; Fenaux, P. P16 gene homozygous deletions in acute lymphoblastic leukemia. Blood 1995, 85, 657-663. [PubMed] 
69. Carrera, C.J.; Eddy, R.L.; Shows, T.B.; Carson, D.A. Assignment of the gene for methylthioadenosine phosphorylase to human chromosome 9 by mouse-human somatic cell hybridization. Proc. Natl. Acad. Sci. USA 1984, 81, 2665-2668. [CrossRef] [PubMed]

70. Nobori, T.; Takabayashi, K.; Tran, P.; Orvis, L.; Batova, A.; Yu, A.L.; Carson, D.A. Genomic cloning of methylthioadenosine phosphorylase: A purine metabolic enzyme deficient in multiple different cancers. Proc. Natl. Acad. Sci. USA 1996, 93, 6203-6208. [CrossRef] [PubMed]

71. Herzog, C.R.; Noh, S.; Lantry, L.E.; Guan, K.L.; You, M. Cdkn2a encodes functional variation of p16ink4a but not p19arf, which confers selection in mouse lung tumorigenesis. Mol. Carcinog. 1999, 25, 92-98. [CrossRef]

72. Zhang, S.; Ramsay, E.S.; Mock, B.A. Cdkn2a, the cyclin-dependent kinase inhibitor encoding p16ink4a and p19arf, is a candidate for the plasmacytoma susceptibility locus, pctr1. Proc. Natl. Acad. Sci. USA 1998, 95, 2429-2434. [CrossRef] [PubMed]

73. Krimpenfort, P.; Quon, K.C.; Mooi, W.J.; Loonstra, A.; Berns, A. Loss of p16ink4a confers susceptibility to metastatic melanoma in mice. Nature 2001, 413, 83-86. [CrossRef] [PubMed]

74. Serrano, M.; Lee, H.; Chin, L.; Cordon-Cardo, C.; Beach, D.; DePinho, R.A. Role of the ink4a locus in tumor suppression and cell mortality. Cell 1996, 85, 27-37. [CrossRef]

75. Sharpless, N.E.; Bardeesy, N.; Lee, K.H.; Carrasco, D.; Castrillon, D.H.; Aguirre, A.J.; Wu, E.A.; Horner, J.W.; DePinho, R.A. Loss of p16ink4a with retention of p19arf predisposes mice to tumorigenesis. Nature 2001, 413, 86-91. [CrossRef] [PubMed]

76. Levine, R.A.; Fleischli, M.A. Inactivation of p53 and retinoblastoma family pathways in canine osteosarcoma cell lines. Vet. Pathol. 2000, 37, 54-61. [CrossRef] [PubMed]

77. Yeudall, W.A.; Crawford, R.Y.; Ensley, J.F.; Robbins, K.C. Mts1/cdk4i is altered in cell lines derived from primary and metastatic oral squamous cell carcinoma. Carcinogenesis 1994, 15, 2683-2686. [CrossRef] [PubMed]

78. Zhang, S.L.; DuBois, W.; Ramsay, E.S.; Bliskovski, V.; Morse, H.C., 3rd; Taddesse-Heath, L.; Vass, W.C.; DePinho, R.A.; Mock, B.A. Efficiency alleles of the pctr1 modifier locus for plasmacytoma susceptibility. Mol. Cell. Biol. 2001, 21, 310-318. [CrossRef] [PubMed]

79. Shearin, A.L.; Hedan, B.; Cadieu, E.; Erich, S.A.; Schmidt, E.V.; Faden, D.L.; Cullen, J.; Abadie, J.; Kwon, E.M.; Grone, A.; et al. The mtap-cdkn2a locus confers susceptibility to a naturally occurring canine cancer. Cancer Epidemiol. Biomark. Prev. 2012, 21, 1019-1027. [CrossRef] [PubMed]

80. Melkamu, T.; Zhang, X.; Tan, J.; Zeng, Y.; Kassie, F. Alteration of microrna expression in vinyl carbamate-induced mouse lung tumors and modulation by the chemopreventive agent indole-3-carbinol. Carcinogenesis 2010, 31, 252-258. [CrossRef] [PubMed]

81. Birney, E.; Stamatoyannopoulos, J.A.; Dutta, A.; Guigo, R.; Gingeras, T.R.; Margulies, E.H.; Weng, Z.; Snyder, M.; Dermitzakis, E.T.; Thurman, R.E.; et al. Identification and analysis of functional elements in $1 \%$ of the human genome by the encode pilot project. Nature 2007, 447, 799-816. [CrossRef] [PubMed]

82. Costa, F.F. Non-coding rnas: Meet thy masters. BioEssays: News Rev. Mol. Cell. Dev. Biol. 2010, 32, $599-608$. [CrossRef] [PubMed]

83. Prensner, J.R.; Chinnaiyan, A.M. The emergence of lncrnas in cancer biology. Cancer Discov. 2011, 1, $391-407$. [CrossRef] [PubMed]

84. Cheetham, S.W.; Gruhl, F.; Mattick, J.S.; Dinger, M.E. Long noncoding rnas and the genetics of cancer. Br. J. Cancer 2013, 108, 2419-2425. [CrossRef] [PubMed]

85. Gibb, E.A.; Brown, C.J.; Lam, W.L. The functional role of long non-coding rna in human carcinomas. Mol. Cancer 2011, 10, 38. [CrossRef] [PubMed]

86. Mercer, T.R.; Dinger, M.E.; Sunkin, S.M.; Mehler, M.F.; Mattick, J.S. Specific expression of long noncoding rnas in the mouse brain. Proc. Natl. Acad. Sci. USA 2008, 105, 716-721. [CrossRef] [PubMed]

87. Gupta, R.A.; Shah, N.; Wang, K.C.; Kim, J.; Horlings, H.M.; Wong, D.J.; Tsai, M.C.; Hung, T.; Argani, P.; Rinn, J.L.; et al. Long non-coding rna hotair reprograms chromatin state to promote cancer metastasis. Nature 2010, 464, 1071-1076. [CrossRef] [PubMed]

88. Morey, L.; Helin, K. Polycomb group protein-mediated repression of transcription. Trends Biochem. Sci. 2010, 35, 323-332. [CrossRef] [PubMed] 
89. Tsai, M.C.; Manor, O.; Wan, Y.; Mosammaparast, N.; Wang, J.K.; Lan, F.; Shi, Y.; Segal, E.; Chang, H.Y. Long noncoding rna as modular scaffold of histone modification complexes. Science 2010, 329, 689-693. [CrossRef] [PubMed]

90. Zhang, Z.; Jones, A.; Sun, C.W.; Li, C.; Chang, C.W.; Joo, H.Y.; Dai, Q.; Mysliwiec, M.R.; Wu, L.C.; Guo, Y.; et al. Prc2 complexes with jarid2, mtf2, and esprc2p48 in es cells to modulate es cell pluripotency and somatic cell reprogramming. Stem Cells 2011, 29, 229-240. [CrossRef] [PubMed]

91. Jovanovic, M.; Hengartner, M.O. Mirnas and apoptosis: Rnas to die for. Oncogene 2006, 25, 6176-6187. [CrossRef] [PubMed]

92. Schickel, R.; Boyerinas, B.; Park, S.M.; Peter, M.E. Micrornas: Key players in the immune system, differentiation, tumorigenesis and cell death. Oncogene 2008, 27, 5959-5974. [CrossRef] [PubMed]

93. Stefani, G.; Slack, F.J. Small non-coding rnas in animal development. Nat. Rev. Mol. Cell Biol. 2008, 9, 219-230. [CrossRef] [PubMed]

94. Lagos-Quintana, M.; Rauhut, R.; Lendeckel, W.; Tuschl, T. Identification of novel genes coding for small expressed rnas. Science 2001, 294, 853-858. [CrossRef] [PubMed]

95. Esquela-Kerscher, A.; Slack, F.J. Oncomirs-Micrornas with a role in cancer. Nat. Rev. Cancer 2006, 6, 259-269. [CrossRef] [PubMed]

96. Calin, G.A.; Sevignani, C.; Dumitru, C.D.; Hyslop, T.; Noch, E.; Yendamuri, S.; Shimizu, M.; Rattan, S.; Bullrich, F.; Negrini, M.; et al. Human microrna genes are frequently located at fragile sites and genomic regions involved in cancers. Proc. Natl. Acad. Sci. USA 2004, 101, 2999-3004. [CrossRef] [PubMed]

97. Garzon, R.; Calin, G.A.; Croce, C.M. Micrornas in cancer. Annu. Rev. Med. 2009, 60, 167-179. [CrossRef] [PubMed]

98. Bartel, D.P. Micrornas: Genomics, biogenesis, mechanism, and function. Cell 2004, 116, 281-297. [CrossRef]

99. Fabian, M.R.; Sonenberg, N.; Filipowicz, W. Regulation of mrna translation and stability by micrornas. Annu. Rev. Biochem. 2010, 79, 351-379. [CrossRef] [PubMed]

100. Friedman, R.C.; Farh, K.K.; Burge, C.B.; Bartel, D.P. Most mammalian mrnas are conserved targets of micrornas. Genome Res. 2009, 19, 92-105. [CrossRef] [PubMed]

101. Kent, O.A.; Mendell, J.T. A small piece in the cancer puzzle: Micrornas as tumor suppressors and oncogenes. Oncogene 2006, 25, 6188-6196. [CrossRef] [PubMed]

102. Hata, A.; Kashima, R. Dysregulation of microRNA biogenesis machinery in cancer. Crit. Rev. Biochem. Molec. Biol. 2015. [CrossRef] [PubMed]

103. Chendrimada, T.P.; Gregory, R.I.; Kumaraswamy, E.; Norman, J.; Cooch, N.; Nishikura, K.; Shiekhattar, R. Trbp recruits the dicer complex to ago2 for microrna processing and gene silencing. Nature 2005, 436, 740-744. [CrossRef] [PubMed]

104. Hammond, S.M.; Bernstein, E.; Beach, D.; Hannon, G.J. An rna-directed nuclease mediates post-transcriptional gene silencing in drosophila cells. Nature 2000, 404, 293-296. [PubMed]

105. Zeng, Y.; Wagner, E.J.; Cullen, B.R. Both natural and designed micro rnas can inhibit the expression of cognate mrnas when expressed in human cells. Mol. Cell 2002, 9, 1327-1333. [CrossRef]

106. Martello, G.; Rosato, A.; Ferrari, F.; Manfrin, A.; Cordenonsi, M.; Dupont, S.; Enzo, E.; Guzzardo, V.; Rondina, M.; Spruce, T.; et al. A microrna targeting dicer for metastasis control. Cell 2010, 141, 1195-1207. [CrossRef] [PubMed]

107. Calin, G.A.; Dumitru, C.D.; Shimizu, M.; Bichi, R.; Zupo, S.; Noch, E.; Aldler, H.; Rattan, S.; Keating, M.; Rai, K.; et al. Frequent deletions and down-regulation of micro- rna genes mir15 and mir16 at 13q14 in chronic lymphocytic leukemia. Proc. Natl. Acad. Sci. USA 2002, 99, 15524-15529. [CrossRef] [PubMed]

108. Chang, T.C.; Wentzel, E.A.; Kent, O.A.; Ramachandran, K.; Mullendore, M.; Lee, K.H.; Feldmann, G.; Yamakuchi, M.; Ferlito, M.; Lowenstein, C.J.; et al. Transactivation of mir-34a by p53 broadly influences gene expression and promotes apoptosis. Mol. Cell 2007, 26, 745-752. [CrossRef] [PubMed]

109. Saito, Y.; Liang, G.; Egger, G.; Friedman, J.M.; Chuang, J.C.; Coetzee, G.A.; Jones, P.A. Specific activation of microrna-127 with downregulation of the proto-oncogene bcl6 by chromatin-modifying drugs in human cancer cells. Cancer Cell 2006, 9, 435-443. [CrossRef] [PubMed]

110. Calin, G.A.; Ferracin, M.; Cimmino, A.; Di Leva, G.; Shimizu, M.; Wojcik, S.E.; Iorio, M.V.; Visone, R.; Sever, N.I.; Fabbri, M.; et al. A microrna signature associated with prognosis and progression in chronic lymphocytic leukemia. N. Engl. J. Med. 2005, 353, 1793-1801. [CrossRef] [PubMed] 
111. Iorio, M.V.; Ferracin, M.; Liu, C.G.; Veronese, A.; Spizzo, R.; Sabbioni, S.; Magri, E.; Pedriali, M.; Fabbri, M.; Campiglio, M.; et al. Microrna gene expression deregulation in human breast cancer. Cancer Res. 2005, 65, 7065-7070. [CrossRef] [PubMed]

112. Lu, J.; Getz, G.; Miska, E.A.; Alvarez-Saavedra, E.; Lamb, J.; Peck, D.; Sweet-Cordero, A.; Ebert, B.L.; Mak, R.H.; Ferrando, A.A.; et al. Microrna expression profiles classify human cancers. Nature 2005, 435, 834-838. [CrossRef] [PubMed]

113. Volinia, S.; Calin, G.A.; Liu, C.G.; Ambs, S.; Cimmino, A.; Petrocca, F.; Visone, R.; Iorio, M.; Roldo, C.; Ferracin, M.; et al. A microrna expression signature of human solid tumors defines cancer gene targets. Proc. Natl. Acad. Sci. USA 2006, 103, 2257-2261. [CrossRef] [PubMed]

114. Yanaihara, N.; Caplen, N.; Bowman, E.; Seike, M.; Kumamoto, K.; Yi, M.; Stephens, R.M.; Okamoto, A.; Yokota, J.; Tanaka, T.; et al. Unique microrna molecular profiles in lung cancer diagnosis and prognosis. Cancer Cell 2006, 9, 189-198. [CrossRef] [PubMed]

115. Kluiver, J.; Poppema, S.; de Jong, D.; Blokzijl, T.; Harms, G.; Jacobs, S.; Kroesen, B.J.; van den Berg, A. Bic and mir-155 are highly expressed in hodgkin, primary mediastinal and diffuse large b cell lymphomas. J. Pathol. 2005, 207, 243-249. [CrossRef] [PubMed]

116. Metzler, M.; Wilda, M.; Busch, K.; Viehmann, S.; Borkhardt, A. High expression of precursor microrna-155/bic rna in children with burkitt lymphoma. Genes Chromosomes Cancer 2004, 39, 167-169. [CrossRef] [PubMed]

117. Ciafre, S.A.; Galardi, S.; Mangiola, A.; Ferracin, M.; Liu, C.G.; Sabatino, G.; Negrini, M.; Maira, G.; Croce, C.M.; Farace, M.G. Extensive modulation of a set of micrornas in primary glioblastoma. Biochem. Biophys. Res. Commun. 2005, 334, 1351-1358. [CrossRef] [PubMed]

118. Garzon, R.; Garofalo, M.; Martelli, M.P.; Briesewitz, R.; Wang, L.; Fernandez-Cymering, C.; Volinia, S.; Liu, C.G.; Schnittger, S.; Haferlach, T.; et al. Distinctive microrna signature of acute myeloid leukemia bearing cytoplasmic mutated nucleophosmin. Proc. Natl. Acad. Sci. USA 2008, 105, 3945-3950. [CrossRef] [PubMed]

119. Meng, F.; Henson, R.; Wehbe-Janek, H.; Ghoshal, K.; Jacob, S.T.; Patel, T. Microrna-21 regulates expression of the pten tumor suppressor gene in human hepatocellular cancer. Gastroenterology 2007, 133, 647-658. [CrossRef] [PubMed]

120. Chan, J.A.; Krichevsky, A.M.; Kosik, K.S. Microrna-21 is an antiapoptotic factor in human glioblastoma cells. Cancer Res. 2005, 65, 6029-6033. [CrossRef] [PubMed]

121. Frankel, L.B.; Christoffersen, N.R.; Jacobsen, A.; Lindow, M.; Krogh, A.; Lund, A.H. Programmed cell death 4 (pdcd4) is an important functional target of the microrna mir-21 in breast cancer cells. J. Biol. Chem. 2008, 283, 1026-1033. [CrossRef] [PubMed]

122. Zhu, S.; Si, M.L.; Wu, H.; Mo, Y.Y. Microrna-21 targets the tumor suppressor gene tropomyosin 1 (tpm1). J. Biol. Chem. 2007, 282, 14328-14336. [CrossRef] [PubMed]

123. Johnson, S.M.; Grosshans, H.; Shingara, J.; Byrom, M.; Jarvis, R.; Cheng, A.; Labourier, E.; Reinert, K.L.; Brown, D.; Slack, F.J. Ras is regulated by the let-7 microrna family. Cell 2005, 120, 635-647. [CrossRef] [PubMed]

124. Akao, Y.; Nakagawa, Y.; Naoe, T. Let-7 microrna functions as a potential growth suppressor in human colon cancer cells. Biol. Pharm. Bull. 2006, 29, 903-906. [CrossRef] [PubMed]

125. Lee, Y.S.; Dutta, A. The tumor suppressor microrna let-7 represses the hmga2 oncogene. Genes Dev. 2007, 21, 1025-1030. [CrossRef] [PubMed]

126. Sampson, V.B.; Rong, N.H.; Han, J.; Yang, Q.; Aris, V.; Soteropoulos, P.; Petrelli, N.J.; Dunn, S.P.; Krueger, L.J. Microrna let-7a down-regulates myc and reverts myc-induced growth in burkitt lymphoma cells. Cancer Res. 2007, 67, 9762-9770. [CrossRef] [PubMed]

127. Harquail, J.; Benzina, S.; Robichaud, G.A. Micrornas and breast cancer malignancy: An overview of mirna-regulated cancer processes leading to metastasis. Cancer Biomark.: Sect. Dis. Markers 2012, 11, 269-280.

128. Zhang, Z.J.; Ma, S.L. Mirnas in breast cancer tumorigenesis (review). Oncol. Rep. 2012, $27,903-910$. [PubMed]

129. Qi, L.; Bart, J.; Tan, L.P.; Platteel, I.; Sluis, T.; Huitema, S.; Harms, G.; Fu, L.; Hollema, H.; Berg, A. Expression of mir-21 and its targets (pten, pdcd4, tm1) in flat epithelial atypia of the breast in relation to ductal carcinoma in situ and invasive carcinoma. BMC Cancer 2009, 9, 163. [CrossRef] [PubMed] 
130. Zhu, S.; Wu, H.; Wu, F.; Nie, D.; Sheng, S.; Mo, Y.Y. Microrna-21 targets tumor suppressor genes in invasion and metastasis. Cell Res. 2008, 18, 350-359. [CrossRef] [PubMed]

131. Boggs, R.M.; Wright, Z.M.; Stickney, M.J.; Porter, W.W.; Murphy, K.E. Microrna expression in canine mammary cancer. Mamm. Genome 2008, 19, 561-569. [CrossRef] [PubMed]

132. Linsley, P.S.; Schelter, J.; Burchard, J.; Kibukawa, M.; Martin, M.M.; Bartz, S.R.; Johnson, J.M.; Cummins, J.M.; Raymond, C.K.; Dai, H.; et al. Transcripts targeted by the microrna-16 family cooperatively regulate cell cycle progression. Mol. Cell. Biol. 2007, 27, 2240-2252. [CrossRef] [PubMed]

133. Liu, Q.; Fu, H.; Sun, F.; Zhang, H.; Tie, Y.; Zhu, J.; Xing, R.; Sun, Z.; Zheng, X. Mir-16 family induces cell cycle arrest by regulating multiple cell cycle genes. Nucleic Acids Res. 2008, 36, 5391-5404. [CrossRef] [PubMed]

134. Takeshita, F.; Patrawala, L.; Osaki, M.; Takahashi, R.U.; Yamamoto, Y.; Kosaka, N.; Kawamata, M.; Kelnar, K.; Bader, A.G.; Brown, D.; et al. Systemic delivery of synthetic microrna-16 inhibits the growth of metastatic prostate tumors via downregulation of multiple cell-cycle genes. Mol. Ther. 2010, 18, 181-187. [CrossRef] [PubMed]

135. Wang, F.; Fu, X.D.; Zhou, Y.; Zhang, Y. Down-regulation of the cyclin e1 oncogene expression by microrna-16-1 induces cell cycle arrest in human cancer cells. BMB Rep. 2009, 42, 725-730. [CrossRef] [PubMed]

136. Bueno, M.J.; Malumbres, M. Micrornas and the cell cycle. Biochim. Biophys. Acta 2011, 1812, 592-601. [CrossRef] [PubMed]

137. Sun, F.; Fu, H.; Liu, Q.; Tie, Y.; Zhu, J.; Xing, R.; Sun, Z.; Zheng, X. Downregulation of ccnd1 and cdk6 by mir-34a induces cell cycle arrest. FEBS Lett. 2008, 582, 1564-1568. [CrossRef] [PubMed]

138. He, L.; He, X.; Lim, L.P.; de Stanchina, E.; Xuan, Z.; Liang, Y.; Xue, W.; Zender, L.; Magnus, J.; Ridzon, D.; et al. A microrna component of the p53 tumour suppressor network. Nature 2007, 447, 1130-1134. [CrossRef] [PubMed]

139. Lujambio, A.; Ropero, S.; Ballestar, E.; Fraga, M.F.; Cerrato, C.; Setien, F.; Casado, S.; Suarez-Gauthier, A.; Sanchez-Cespedes, M.; Git, A.; et al. Genetic unmasking of an epigenetically silenced microrna in human cancer cells. Cancer Res. 2007, 67, 1424-1429. [CrossRef] [PubMed]

140. Wang, Y.; Blelloch, R. Cell cycle regulation by micrornas in embryonic stem cells. Cancer Res. 2009, 69, 4093-4096. [CrossRef] [PubMed]

141. Lal, A.; Kim, H.H.; Abdelmohsen, K.; Kuwano, Y.; Pullmann, R., Jr.; Srikantan, S.; Subrahmanyam, R.; Martindale, J.L.; Yang, X.; Ahmed, F.; et al. P16(ink4a) translation suppressed by mir-24. PLoS ONE 2008, 3, e1864. [CrossRef] [PubMed]

142. Malhas, A.; Saunders, N.J.; Vaux, D.J. The nuclear envelope can control gene expression and cell cycle progression via mirna regulation. Cell Cycle 2010, 9, 531-539. [CrossRef] [PubMed]

143. Wang, P.; Zou, F.; Zhang, X.; Li, H.; Dulak, A.; Tomko, R.J., Jr.; Lazo, J.S.; Wang, Z.; Zhang, L.; Yu, J. Microrna-21 negatively regulates cdc25a and cell cycle progression in colon cancer cells. Cancer Res. 2009, 69, 8157-8165. [CrossRef] [PubMed]

144. Sarkar, S.; Dey, B.K.; Dutta, A. Mir-322/424 and -503 are induced during muscle differentiation and promote cell cycle quiescence and differentiation by down-regulation of cdc25a. Mol. Biol. Cell 2010, 21, 2138-2149. [CrossRef] [PubMed]

145. Kabir, F.M.L.; DeInnocentes, P.; Bird, R.C. Altered microrna expression profiles and regulation of ink4a/cdkn2a tumor suppressor genes in canine breast cancer models. J. Cell. Biochem. 2015, in press.

(C) 2015 by the authors; licensee MDPI, Basel, Switzerland. This article is an open access article distributed under the terms and conditions of the Creative Commons by Attribution (CC-BY) license (http://creativecommons.org/licenses/by/4.0/). 